\title{
Corporate Social Responsibility Program (CSR) Petrokimia Gresik Limited Company (LTD) in Community Development
}

\author{
Didik Hariyanto $^{1}$, Afrilia Ernes Natasya ${ }^{2}$, Djarot Meidi Budi Utomo ${ }^{3}$ \\ \{didikhariyanto@umsida.ac.id ${ }^{1}$, afrilia.ernes.natasya@gmail.com ${ }^{2}$ \} \\ Faculty of Social Science and Political Science, Universitas Muhammadiyah Sidoarjo ${ }^{1,2,3}$
}

\begin{abstract}
This study aims to determine the implementation of Petrokimia Gresik Ltd Corporate Social Responsibility program in Community Development in the Healthy Village of Mud Village in Gresik Regency. This study uses qualitative methods, data obtained through interviews, participant observation and documents. Data analysis using descriptive analysis method using the Miles and Huberman models.The results of this study indicate that the implementation of Petrokimia Gresik Ltd Corporate Social Responsibility program in the field of Healthy Village has not shown the form of Community Development but rather tends to be only a health service to the community.The program is still centralized where the implementer of activities are carried out by (public relation) companies starting from determining community needs, planning, implementation, control, and evaluation. Therefore, the community does not participate further in implementing the program.
\end{abstract}

Keywords: Corporate Social Responsibility, Community Development, Public Relation, society participation, Empowermen.

\section{Introduction}

The growth of big corporates is indeed inseparable from the support of the people living in the environment surrounding the company. The corporation will be acknowledged by the public if it can contribute towards the community [1] and be responsible upon the environment. These forms of responsibility are done by an organization in a corporation called Corporate Social Responsibility (CSR) [2]. In compliance with the Constitution mandate no. 19 of 2003 on State-Owned Enterprises and no. 40 of 2007 concerning about Limited Liability Companies and as a form of apprehension for the economic growth of society as well as the social environment of the public, such companies as like Petrokimia Gresik performs a CSR program with community empowerment. Performs a CSR program based on community empowerment (community development). One of these forms of community development in corporate Petrokimia Gresik. Is improving public health through a Kampung Sehat program. In order to unveil and investigate the application of the CSR program at Petrokimia Gresik as a form of community development, the researcher conducted a re-review of the program implementation process that implemented from the beginning of implementation until the end of program enactment. The program implementation process will provide a re-description of community development accomplished by Petrokimia Gresik. In developing the community, specifically in improving public health. 


\section{Methods}

This research make use of descriptive qualitative research type, which is oriented to explanation of natural descriptive data from the experimented object, Hussle [3] in order to give a clearer portray of social situations through an in-depth description of utterance, writing and behaviour that can be observed from a specific individual, group, community, or organization in a specified setting context studied from a whole, comprehensive and holistic perspective [4] in quest of understanding the implementation of CSR through the point of view of community development. The research was conducted in direct approach intensively, detailed and in-depth on implementation CSR in Petrokimia Gresik Ltd. In this research, the first informant was the staff of the Public Relations Department of Petrokimia Gresik Ltd., the second informant was the staff of Public Relation Department of Petrokimia Gresik Ltd., the third informant was Petrokimia Gresik Hospital Staff, the fourth informant was the community figures in Lumpur village, and the last informant was the receiver community of Kampung Sehat program in Lumpur village. Data collection techniques used through (1) Observation, (2) interviews and (3) company documents. Interviews are conducted through indepth interviews irregularly and focused on digging information to find rigid information or single and freer information. Questions and statements can drift like a casual conversation. The data were analyzed using Miles and Huberman model, which explains that the data analysis includes three flow of activities i.e. data reduction, data presentation and conclusion.

\section{Results}

\subsection{Corporate Social Responsibility}

According to Farmer and Hogue, Corporate Social Responsibility is an action taken by a company that is valued by the community for the future, by helping optimally in providing the necessary social needs such as goods and services by the community around the company environment. In the description mentioned, Farmer and Hogue emphasize corporate committees to be able to deliver what society needs [5]. Corporate cannot merely provide goods and afford services to goods and services consumers, yet as well as assist to solve problems of the community. From the description above, it is clear that the implementation of corporate social responsibility program has broader scope inside. All the programs attained by the company are based on economic, social and environmental aspects. CSR programs that are executed continuously and not short-termed in nature. The corporation does not merely distribute its generosity, yet strives to keep the program occurred sustainable[6].

\subsection{Community Development}

In essence, community empowerment can be seen in the community participation in activities or programs were undertaken i.e. activities in taking initiatives, planning, implementation, monitoring and evaluation, and management as well as maintenance [7]. According to Hadi community development or community empowerment is a strategy to develop people's ability in analyzing the problems they engage and determine its solutions as 
well. Also mentioned that there are four approaches to understanding community development meaning: (1) Community development as a process; (2) Community development as a method; (3) Community development as a program; and (4) Community development as an impetus. Community development is a process of social activity in which the community organizes itself to (1) Identify the necessities and problems that exist within society; (2) Analyse the state of society, in the aspect of strengths, weaknesses, opportunities and threats towards the community; (3) Choosing alternative policies; and (4) Implements the alternatives that depend on the community's own resource [8].

\subsection{Community Participation}

According to Nasdian, stated that participation is active processes that taken by community members themselves, guided by their own ways of thinking, using institutions and mechanisms, where they can express control effectively[9]. The starting point of participation is deciding, acting, then, they reflected the action as the conscious subjects. Also clarified that participation in community development should generate maximum participation by the aim that all people in the community can be effectively involved in community processes and activities [5].

People-emphasized participations have a role in decision-making. Community development should always strive to maximize participation, by the aim of getting everyone in the community to be actively involved in community processes and activities, as well as generate the future of society and individuals. Therefore, participation is an important part of empowerment and growth of consciousness. The more people who become active participants and the more they fulfill the participation, the more ideal the ownership and process of society as well as the inclusive processes that will be apprehended [8]. 


\section{Discussion}

The progress of the enterprise's world today is inseparable from its external environment, so the corporation always tries to take an action in the form of responsibility towards company external environment (local community) in order for the company's existence to earn recognition from the local community. CSR emphasizes the company's commitment to deliver what the society need. Therefore, the corporation cannot merely provide goods and provide services to the consumer of goods and services, yet as well as assist to solve problems of the community[6]. Hence, the harmonious relationship between the company and the community around the company must be built to maintain the sustainability of the corporation[10]. Corporate social responsibility program of Petrokimia Gresik Ltd. shows evidence that Petrokimia Gresik Ltd. wanted to grow altogether with its environment [11]. Theoretically, in applying social responsibility, the corporation should have the strategies of CSR implementation so that companies ought to accomplish several stages or steps before stepping on the implementation of a CSR program. At this stage, the corporation will know the importance of a CSR program, so that companies can identify the aspects that need to be prioritized, which then perform guidelines in the implementation of CSR programs. In addition, along with the planning phases, the objectives of CSR are executed according to the efficiency targets.

\subsection{Implementation of Kampung Sehat CSR Program PT Petrokimia Gresik Ltd.}

In analyzing the necessities of the surrounding community, Petrokimia Gresik Ltd., through the Department of Public Relation, involves village government, community figures as well as village communities in carrying out regular meetings. By performing needs analysis, the corporation can understand what the community wants and needs. The involvement of village government, community figures, and village communities are very significant. The involvement of such parties facilitates the corporation in exploring the ideas for programs that become the common necessities of society instead of personal necessities. Furthermore, companies involve such parties because they know the condition directly. Determination of Community Needs in Implementation Petrokimia Gresik CSR Program with program of Kampung Sehat, the determination of community necessities can be accomplished with two types of centralization and decentralization.The determination of needs with pure centralization is done based on the corporation, grounded on the ranking of the local community necessities, where the rank data gained by the company comes from the regency government. While decentralization is based on ideas from ring-I company community through submitted proposals or offered to companies as disclosed by Public Realtion of Petrokimia Gresik Ltd. Mr. Suwandono.

The proposal is analyzed and reviewed by the corporation. Additionally, the ideas of decentralization can also come from the corporation, that is where the meeting of all parties related to Petrokimia Gresik Ltd. is given suggestion to the ideas of community needs, and then the community makes a proposal. From the results of research that has been described, that in the implementation of CSR program, it is essential to identify the main problem first.

Community involvement in the CSR program of Petrokimia Gresik Ltd. Kampung Sehat lies on the analysis of the community necessities, as those who are more in understanding the environment and more aware of the problems engaged according to their needs as stated by 
the coordinator of Petrokimia Hospital, Mr. Syahid stated: "Kampung Sehat is usually having inputs from the residents. Programs needed by citizens, we'll follow that up e.g. data collection for Papsmir. Community participation in defining the problems they encounter is completed by acquiescing proposals to the corporation. Ife describes such involvement as a decentralization that is a characteristic of participation. Uphoff and Cohen [12], in community development, The form of community participation of Lumpur village in Kampung Sehat of Petrokimia Gresik Ltd. program aside from participating in the determination of community needs is also involved in the Kampung Sehat program survey that has been offered by the company. However, the community is only limited as an informant, as the recipient of the Kampung Sehat program. Here the community will provide an assessment of the program that has been performed by the corporation whether it has been appropriate towards the target or requires to be improved in the meantime. This is one of the concepts in community participation of program implementation of community development, which require communities to be involved in the program surveys.

In the program funds allocating, expenses can be accomplished by two stages namely: (1) Estimating human resources and necessary purchases to discharge each activity and (2) estimate the cost of expenditure and the availability of resources[13]. Aside for that, Petrokimia Gresik Ltd. establishes controls or monitoring that will be prepared to observe every process in implementing CSR program later on while progressing in the field. The controls can grasp the shortcomings of the program so that in the implementation of future CSR programs can be improved in order for the goals to be fully achieved later on. According to Cutlip, the planning process can use several phases: (1) Defining roles and missions; (2) Determining the main outcome area; (3) Identifying and specifying indicators of effectiveness; (4) Selecting and targets setting; (5) Preparing action plans which consisting of programming, scheduling, budgeting, establishing accountability and reviewing as well as reconciling; (6) Establishing control; (7) Communicating; and (8) Implementing[13]. From the stages of CSR program planning of Kampung Sehat field that has been carried by Petrokimia Gresik Ltd. is a combination of program planning phases by.

\subsection{CSR Program Implementation of Kampung Sehat of Petrokimia Gresik Ltd.}

In the implementation phase of the CSR program, Petrokimia Gresik Ltd. involves Petro hospital party as medical staff in the enactment of field programs and village apparatus as the provider of facilities and infrastructure needed during the activity. Through such cooperation, the CSR program implementation of Kampung Sehat can be well realized. Implementation of CSR programs can be managed with various patterns i.e., Centralization program where the company as the main activity implementer or organizers such as venues provision for the taken activities; the Decentralization program where the activities are outside the corporation scope while the company acts as supporting activities both in the material and sponsorship form; Combined programs are usually done for community empowerment programs where initiatives, funding, and implementation of activities are carried out in a participatory approach with beneficiaries [14]. Implementation of Kampung Sehat program by Petrokimia Gresik Ltd. is done in the form of decentralization and combination program. Kampung Sehat is a decentralization program where the implementation takes place in each village that receives health services. The program services are handled by the Petrokimia Gresik hospital as human resources in accordance with the engaged program competence and the village apparatus as the provider of facilities and infrastructure during the activity. Additionally, as 
well as monitoring Kampung Sehat programs conducted by the Department of Partnership and Community Development.

\subsection{Performance of Kampung Sehat of Petrokimia Gresik Ltd. in Lumpur Village}

The system used in the implementation of the Kampung Sehat program by Petrokimia Gresik Ltd. is using a polyclinic system where the treatment of illnesses that are mostly suffered by the community around the corporation for free in once every month only for people who are living in the ring-I. The process of free medical treatment is done for two hours. Aside from free treatment, the form of Kampung Sehat activities conducted with prevention, socialization of health activities through brochures (promotive).

The implementation of the CSR program of Petrokimia Gresik Ltd. was previously accomplished in form of physical assistance. As the program progresses, Petrokimia Gresik Ltd. realizes that for the implementation of non-community-based programs, it is not fulfilling towards the necessities of the community. Community development is a community development activity that is directed to escalate community access in achieving better socioeconomic cultural conditions when compared to before the community development activities. So that people in the place are expected in becoming more self-reliant with the quality of life and better welfare.

Such a program can provide knowledge and understanding to the community regarding with the goals on which the program is based upon. In the implementation of Kampung Sehat program of Petrokimia Gresik Ltd., counseling and training is only given before the implementation of Kampung Sehat program has not supported normally is usually conducted while waiting for the patient. The training or extension program provided as described in the data analysis above is how to be able to wash the hands properly and appropriately, how to brush your teeth, and elderly gymnastics as stated by Mr. Suwandono: "A lot, so if before starting a Kampung Sehat activities, there will be a decent handwashing counseling, maintaining health, healthy lifestyle.

\subsection{The success CSR Program of Petrokimia Gresik Ltd. in Lumpur Village}

The success of the CSR program in Kampung Sehat area of Petrokimia Gresik Ltd. can be seen from the many participants of the program. The evaluation undertaken is part of the effort to enhance the performance of Kampung Sehat in CSR program implementation in the future, so that the program carried is not static, yet dynamic and being better. So that the program in realizing community development can be achieved to increase unconventionality in society, especially the community of Lumpur village.

In carrying out CSR program in the Kampung Sehat, Petrokimia Gresik Ltd. has two parameters to measure the success and effectiveness of such program, namely, first, internal corporation parameters consisting of operational implementation of CSR program of Kampung Sehat by observing at human resources running and fund usage. Second, the corporation's external parameters consist of community involvement in the company's Kampung Sehat program, the level of community health improvement as well as the level of community satisfaction. 


\section{Conclusion}

The results of the study show that the implementation of the Corporate Social Responsibility program in the field of Healthy Villages run by PT Petrokimia Gresik has not yet demonstrated the form of Community Development. Community are more need form of providing health services. The community can not build a strength that relies on the independence and participation of the group itself. The Kampung Sehat program still coordinates implementation, carried out by companies such as planning, implementation, control and monitoring and evaluation. Society prepare to get services than having to empower their own groups. Communities being patients who receive health services have not involved human resources in community development.

Acknowledgement. We hereby thank you to Universitas Muhammadiyah Sidoarjo for supporting our research publication.

\section{References}

[1] A. N. L. Kotler, Philip, Corporate Social Responsibility. 2005.

[2] E. Ardianto, "PR On The NET. A New Perspective of HumansNo Title," Mediator., vol. 2 NO 1, no. PR on the NET. A Public Relations New Perspective, p. 32, 2011.

[3] Lukiati dan Yanti., Makna Corporate Social Responsibilty Bagi Praktisi Public Relations di Bandung. Bandung: Universitas Padjajaran, 2012.

[4] Fajarina., "Analysis of the Public Relations Function of PT Indofood CBP Sukses Makmur in the Implementation of the Corporate Social Responsibility Program in Makassar," Acta released Vol. 10 No.1 2014., vol. 10 NO 1, no. Corporate Public Relation, p. 1, 2014.

[5] R. N. \& H. Farmer, Corporate Social Responsibility, DC Healt and Company. InTrans Publishing Malang, 2008.

[6] Wahyudi Isa and Busyra Azheri, Corporate Social Responsibility: Principles, Arrangements and Implementation. 2011.

[7] R. Kriyantono, Theory of Public Relations of Western and Local Prespective, Research and Practice Applications. 2014.

[8] Sumardiyono Eko, Evaluation of Implementation of Community Development in the Acquisition of Green PROPER. Environmental Sciences. Semarang: Diponegoro University, 2007.

[9] I. and T. N. Rosyida, "Community Participation," Transdisiplin Sosiol. ,komunikasi, dan Ekol. Mns., vol. 06 No 01, no. Social, 2011.

[10] PT Petrokimia Gresik, "Sustaibility Report," 2012.

[11] PT Petrokimia Gresik, "Annual Report," 2011.

[12] Ife Jim and F Tesoriero., Community Development: Alternative Community Development in the Third Edition of Globalization. (Community Development: Community Development Alternative in Globalization Era Third Edition). Yogyakarta: Student Library. 2014.

[13] A. H. C. dan G. M. B. Cutlip, Scott M, "Effective Ninth Edition Public Relations," 2011, p. 45.

[14] Wibisono Yusuf, Dissecting the Concept and Application of Corporate Social Responsibility. 2007. 
